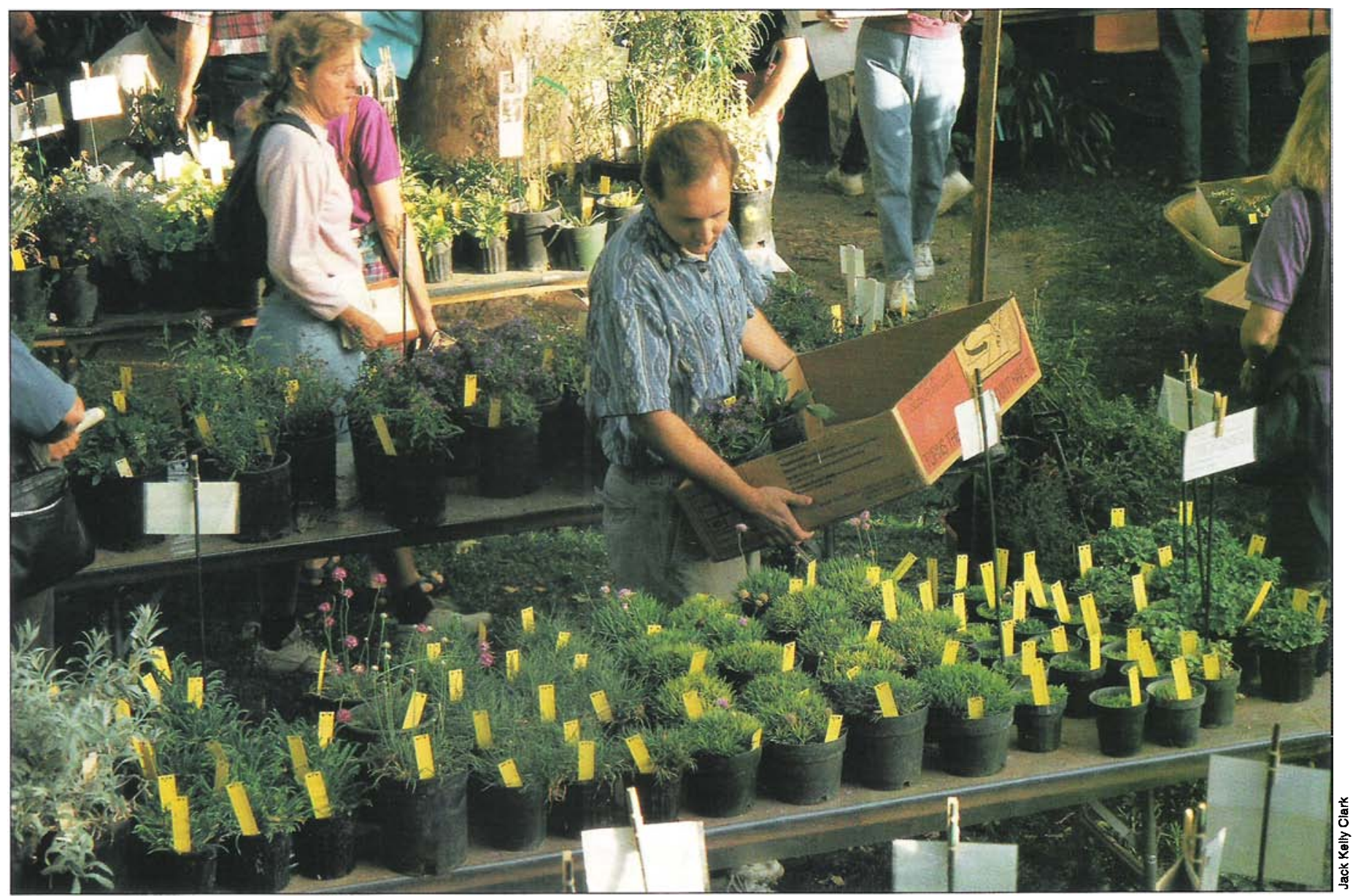

Customer inspecting sale plants.

\title{
IPM reduces pesticide use in the nursery
}

\author{
Mary Louise Flint $\square$ Steve H. Dreistadt $\square$ Ellen M. Zagory $\square$ Robin Rosetta
}

\section{Study shows that cus- tomers ignore or don't discern some plant damage.}

\author{
Regular monitoring by a well- \\ trained pest manager can reduce \\ insecticide use in the nursery with- \\ out reducing ornamental plant \\ quality. Complete control of pests \\ is not required to sell certain \\ plants. A case in point is a plant \\ sale at the UC Davis Arboretum, \\ where customers ignored or did \\ not recognize some types of pest \\ damage.
}

For the $\$ 450$ million worth of woody ornamental plants sold each year by California nurseries, research on plant protection ranks as the number-one priority by members of the California Association of Nurserymen. Research is needed, said nursery owners in a 1990 survey, to develop efficient monitoring techniques and treatment guidelines that will facilitate safe, economical production of quality plants. Nurseries also must adapt to an increasing demand for California native, droughttolerant and pest-resistant species. 
A step in this direction is an IPM program for the University of California Davis Arboretum, which is being developed with assistance from the Statewide Integrated Pest Management (IPM) Project. The arboretum collects, propagates, conserves and promotes use of native California plants and exotic species from other regions with a similar climate. Plants are nursery grown from fieldcollected seeds or cuttings, then planted for research and teaching use in the arboretum. Each year volunteers, members of the Friends of the Davis Arboretum, also grow about 1,000 species or varieties of plants that are sold to support arboretum activities.

The IPM program being developed includes monitoring techniques, quantifying the relationship between pest density and plant damage, and assessing the effectiveness of low-toxicity pesticides and beneficial insect releases in the arboretum nursery. To develop treatment thresholds, customer discrimination of aesthetic injury is also being evaluated. The program's objectives are to increase management effectiveness and reduce pesticide use in the arboretum nursery, and to develop information and techniques useful to commercial nurseries.

\section{Developing an IPM program}

During 1991, insect density, damage and treatment efficacy were determined on five native California species used widely in landscapes. Study plants were toyon (Heteromeles arbutifolia var. cerina), coyote bush (Baccharis pilularis 'Pigeon Point'), western redbud (Cercis occidentalis 'Albus'), valley oak (Quercus lobata) and California lilac (Ceanothus 'Concha', believed to be a hybrid of $C$. papillosus var. roweanus and C. impressus).

The plants were grown in 1-gallon pots, except for oak and redbud. Oak were in 3.5-gallon tree pots and redbud were in Deepot tree tubes (21/2 $\times 10$ inches). Except for the 3-year-old oaks, plants were less than 1 year old. They were started from seed (oak and redbud) or cuttings in the greenhouse in fall or winter, transferred to outdoor shade during winter or spring and then moved to unshaded gravel beds in spring, except for redbud, which remained under shade screens during the entire growing season.

Approximately 90 plants of each species (except for Ceanothus, which numbered 45 plants) were divided equally into three treatment groups with three replicates each. Plants were untreated or sprayed with insecticidal soap (2\% Safer Insecticide Concentrate) to control insects and damage. Quercus were sampled and sprayed as in figure 2. Baccharis, Ceanothus, Cercis and Heteromeles were sampled every
2 weeks from late July through September.

Plants were untreated, sprayed once (in August) or twice (in August and September) during the sample period. In addition, all Baccharis were sprayed once monthly during May, June and July, and all Heteromeles were sprayed 10 times from April through July to control aphids. These applications were made before plants were moved outdoors from the lath house and before the staff was available to conduct sampling. Applications were made because of concern that very young rooting plants might be readily damaged by insects, although the relationship between pest density and damage is unknown.

All insects and damage presence or absence were recorded on three leaves per plant (except for the Baccharis), one leaf each from the lower, middle and upper one-thirds of the plant. Five each of terminal and distal leaves were sampled on Baccharis. The chlorotic or necrotic leaf spots were counted on oak. Nine plants from each treatment group were sampled.

Customer discrimination of aesthetic damage to plants was assessed for the above species (except oaks) during the Friends of the Davis Arboretum plant sale on the last Saturday in September 1991. Discrimination of damage to valley oaks and Verbena hybrida was assessed during the September 1990 sale. Before the sale, plant damage, height and form (number of branches, leaves and/or leaf size) were measured. Plants with little or no apparent damage were paired with more damaged plants of similar form, except for Baccharis, which could only be paired by branch length and number because the more damaged plants also had smaller leaves. Plants were unobtrusively tagged, randomly dispersed within same species blocks and presented for sale.

Inventory of study plants was taken at 15-minute intervals during the 8 a.m. to 2 p.m. sales, and the time when a customer removed a plant from the sale table was recorded. Customer discrimination was determined by comparing the average time it took customers to select plants showing little or no damage with the time taken to select more damaged plants. Surveys were distributed to customers (139 were returned) to gather demographic information on education and income, and reasons for patronizing the Friends sale.

Beginning in the spring of 1990, an IPM intern was assigned to make pest management decisions and to treat all nursery plants. Before 1988, no records of treatment were kept by the arboretum, and decisions and pesticide applications were made by several persons.

The IPM intern, experienced in horticulture and pest management, inspected plants of each species and variety weekly and recorded any insects or damage present. Because no quantitative monitoring and thresholds have been developed, except as indicated below, the IPM intern treated the nonresearch plants when she judged it necessary to prevent or minimize damage.

\section{Monitoring reduced pesticide use}

Decisions resulting from regular monitoring by a person formally trained in pest management resulted in a $40 \%$ decrease in insecticide spraying in the nursery in 1990 and 1991, compared with the previous 2 years (fig. 1). Approximately the same number of plants was sold at both sales, with similar revenues. Organophosphate and pyrethroid insecticides were eliminated during this period. Insecticidal soap, Bacillus thuringiensis and pyrethrins were the only insecticides sprayed.

Ant control with ant stakes (Grant's Kills Ants, $0.03 \%$ arsenic with bait) was also begun in 1990 to eliminate volunteer 
worker complaints about ants crawling up their legs and arms. It was not determined whether ant control, increased biological control or other factors may have reduced pest populations and prompted less spraying because no quantitative sampling or treatment thresholds were available or used for nonresearch plants. It is believed, however, that pesticide use was reduced not because of any changes in pest abun- dance but because decisions were made by a person formally trained in pest management who monitored plants regularly and treated only when she judged it necessary to prevent or minimize damage.

Each research plant hosted several plant-feeding species, but most caused little or no apparent damage (table 1). Insecticidal soap appeared to temporarily control most soft-bodied, exposed feeding

TABLE 1. Insects and mites infesting California native plants in the Davis Arboretum nursery

\begin{tabular}{|c|c|c|}
\hline Plant species & Pests ${ }^{*}$ & Potential pests ${ }^{\dagger}$ \\
\hline $\begin{array}{l}\text { Baccharis pilularis } \\
\text { 'Pigeon Point' }\end{array}$ & $\begin{array}{l}\text { Lace bug, Corythucha morrilli } \\
\text { Aphids }\end{array}$ & $\begin{array}{l}\text { Leafminer, Liriomyza sp. } \\
\text { Tobacco flea beetle, Epitrix hirtipennis } \\
\text { Greenhouse whitefly, Trialeurodes } \\
\text { vaporariorum }\end{array}$ \\
\hline Ceanothus 'Concha' & $\begin{array}{l}\text { Ceanothus stem gall moth, } \\
\text { Periploca ceanothiella }\end{array}$ & $\begin{array}{l}\text { Aphids, including: Aphis ceanothi } \\
\text { Leafminer, Tischeria immaculata } \\
\text { Diamondback moth, Plutella xylostella } \\
\text { Whiteflies }\end{array}$ \\
\hline $\begin{array}{l}\text { Cercis occidentalis } \\
\text { 'Albus' }\end{array}$ & Katydids & $\begin{array}{l}\text { Twospotted mite, Tetranychus urticae } \\
\text { Ash whitefly, Siphoninus phillyreae } \\
\text { Thrips, including: bean thrips, } \\
\text { Caliothrips fasciatus; onion thrips, } \\
\text { Thrips tabaci }\end{array}$ \\
\hline $\begin{array}{l}\text { Heteromeles arbutifolia } \\
\text { var. cerina }\end{array}$ & Aphids & $\begin{array}{l}\text { Ash whitefly, Siphoninus phillyreae } \\
\text { Lace bug, Corythucha incurvata } \\
\text { Thrips } \\
\text { Leafhoppers }\end{array}$ \\
\hline Quercus lobata & Oak leaf phylloxera & $\begin{array}{l}\text { Aphids } \\
\text { Mites, including an eriophyid: } \\
\text { Rhyncaphytoptus megarostris }\end{array}$ \\
\hline
\end{tabular}

* Species that apparently caused significant damage and were abundant enough to prompt control actions. ${ }^{\dagger}$ Species that apparently caused little or no damage, even on untreated plants; rarely observed species are not listed.

TABLE 2. Nursery customer preference, mean (standard deviation), for plants with little or no damage versus more damaged plants sold at the Friends of the Davis Arboretum Plant Sales, September 1990 and $1991^{*}$

\begin{tabular}{|c|c|c|c|c|}
\hline Plant species & $\begin{array}{l}\text { Year } \\
\text { sold }\end{array}$ & $\begin{array}{l}\text { Number } \\
\text { of plants }\end{array}$ & $\begin{array}{c}\text { Mean (SD) } \\
\text { apparent damage }\end{array}$ & $\begin{array}{l}\text { Mean (SD) minutes } \\
\text { until plant selected } \dagger\end{array}$ \\
\hline & & & Damage not discriminated & \\
\hline \multirow[t]{2}{*}{$\begin{array}{l}\text { Cercis occidentalis } \\
\text { 'Albus' }\end{array}$} & 1990 & $\begin{array}{l}10 \\
10\end{array}$ & $\begin{array}{l}13(8) \% \text { of leaves chewed } \\
32(9) \% \text { of leaves chewed }\end{array}$ & $\begin{array}{rr}33 & (9) \mathrm{a} \\
26 & (10) \mathrm{a}\end{array}$ \\
\hline & 1991 & $\begin{array}{l}16 \\
16\end{array}$ & $\begin{array}{l}10(9) \% \text { of leaves chewed/necrotic } \\
60(17) \% \text { of leaves chewed/necrotic }\end{array}$ & $\begin{array}{ll}72 & (90) a \\
87 & (66) a\end{array}$ \\
\hline $\begin{array}{l}\text { Heteromeles arbutifolia } \\
\text { var. cerina }\end{array}$ & 1991 & $\begin{array}{l}23 \\
23\end{array}$ & $\begin{array}{c}\text { none } \\
8(6) \% \text { of leaves necrotic }\end{array}$ & $\begin{array}{l}126(142) \mathrm{a} \\
142(137) \mathrm{a}\end{array}$ \\
\hline Verbena hybrida & 1990 & $\begin{array}{l}16 \\
16\end{array}$ & $\begin{array}{c}\text { none } \\
8(3) \% \text { of leaves mined }\end{array}$ & $\begin{array}{cc}94 & (66) a \\
120 & (69) a\end{array}$ \\
\hline & & & Damage discriminated & \\
\hline Quercus lobata & 1990 & $\begin{array}{l}10 \\
10\end{array}$ & $\begin{array}{l}2 \text { (0.3) spots } / \mathrm{cm} \text { of leaf length } \\
45 \text { (27) spots } / \mathrm{cm} \text { of leaf length }\end{array}$ & $\begin{array}{cc}32 & (14) a \\
113 & (59) b\end{array}$ \\
\hline Ceanothus 'Concha' & 1991 & $\begin{array}{l}11 \\
11\end{array}$ & $\begin{array}{c}\text { none } \\
2(0.9) \text { stem galls per plant }\end{array}$ & $\begin{array}{rr}16 & (4) \mathrm{a} \\
37 & (30) \mathrm{b}\end{array}$ \\
\hline $\begin{array}{l}\text { Baccharis pilularis } \\
\text { 'Pigeon Point' }\end{array}$ & 1991 & $\begin{array}{l}25 \\
25\end{array}$ & $\begin{array}{l}25(22) \% \text { of leaves stippled } \\
72(18) \% \text { of leaves stippled }\end{array}$ & $\begin{array}{l}326(96) a \\
238(165) b\end{array}$ \\
\hline
\end{tabular}

*Apparent damage is significantly different ( $P<0.001, t$ test) for all paired comparisons.

†Paired mean sale times followed by different letters are significantly different $(P<0.05, t$ test).

insects, such as aphids and whiteflies. However, most insect species on the study plants were too varied and few to provide a good comparison among treatments. Foliar soap sprays during summer did not control stem gall moths (Periploca ceanothiella) on Ceanothus nor did they reduce katydid chewing on redbud.

Insecticidal soap significantly reduced ( $P>0.05$, Tukey's test) leaf stippling caused by the lace bugs (Corythucha morrilli) on coyote bush and reduced their number and their black, varnishlike excrement. However, monthly applications were not frequent enough to prevent extensive damage. About $50 \%$ of the leaves were stippled on plants sprayed five times from May through September, compared with $90 \%$ of leaves damaged on Baccharis sprayed three or four times.

Soap effectively controlled phylloxera feeding on valley oak foliage, greatly reducing both insect numbers (fig. 2) and damage. Little is known about this undescribed species of oak leaf phylloxera, which has only recently attracted attention as a pest. Soon after leaves flush in spring, these tiny, orangish insects colonize the undersides of foliage to suck plant juices (see photo, p. 5). Eggs, nymphs and wingless adults occur through summer into winter, until leaves drop about December. Winged forms were observed only during October. This phylloxera causes obvious yellowish chlorotic and brownish necrotic

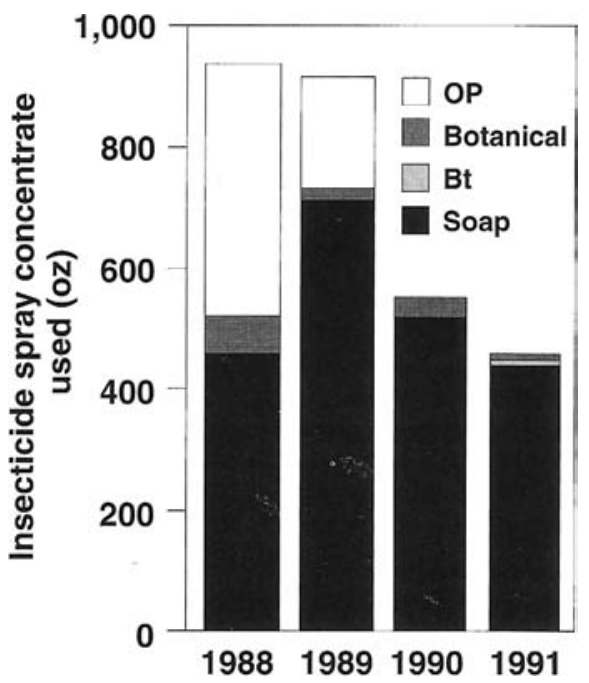

Fig. 1. Ounces of insecticide spray concentrate used in the UC Davis Arboretum nursery in 1988 and 1989 (before IPM) and in 1990 and 1991 (after IPM development). Insecticides were chlorpyrifos (OP), pyrethroids during 1988 and 1989 or pyrethrins during 1990 and 1991 (Botanical), Bacillus thuringiensis $(\mathrm{Bt})$ or insecticidal soap (Soap). Figure excludes 107 oz of ant bait (Grant's stakes) used in 1990 and 119 oz in 1991. 
spots on upper and lower leaf surfaces (see photo, p.7), and nursery customers disdain heavily spotted plants (table 2).

Insecticidal soap apparently caused significant phytotoxicity on redbud $(\mathrm{P}<0.05$, Tukey's test). Necrotic spots or patches occurred on about $50 \%$ and $80 \%$ of redbud leaves sprayed once or twice, respectively. Redbud, the most sun-sensitive of the five species studied, was grown under shade screens, unlike the others. Even unsprayed plants developed necrotic areas on $20 \%$ of their leaves due to drought stress or mineral toxicity, damage that looks like insecticide phytotoxicity. California lilac, coyote bush, toyon and valley oak exhibited no phytotoxicity even though they were sprayed with soap up to 7 times (oak) or 12 times (toyon) from April through September.

Toyon were treated for aphids in the lath house, but experienced no insect pest problems, once they were moved outdoors. When all insect life stages were combined, even untreated toyon averaged

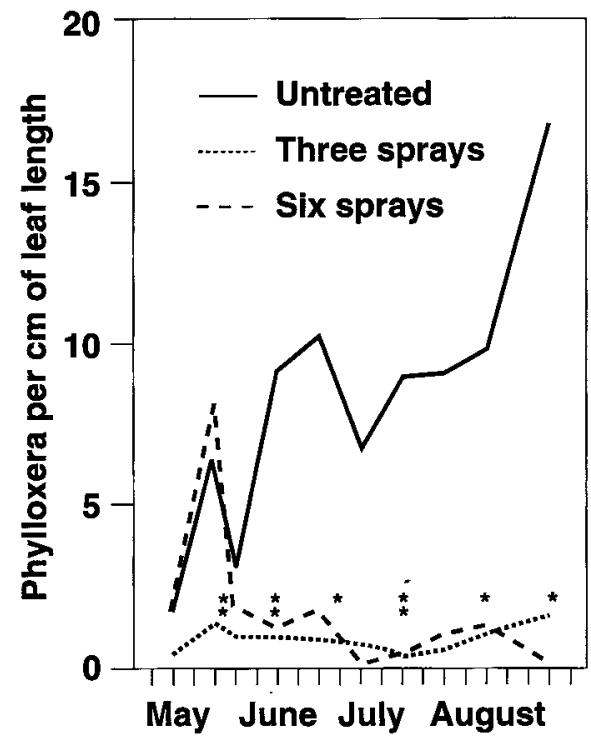

Fig. 2. Oak leaf phylloxera (eggs, nymphs and adults combined) per $\mathrm{cm}$ of leaf length on potted valley oak sprayed with insecticidal soap or untreated in the Davis Arboretum nursery in 1991. Asterisks indicate spray dates for oaks treated six times (single and double asterisks) or three times (double asterisks only). On all sample dates after the first spray (May 29), phylloxera densities are significantly lower ( $P<0.05$, Tukey's test) on sprayed oaks as compared with untreated oaks, but phylloxera are not significantly different on oaks sprayed three times versus oaks sprayed six times. All oaks were sprayed once on May 6 before sampling began.

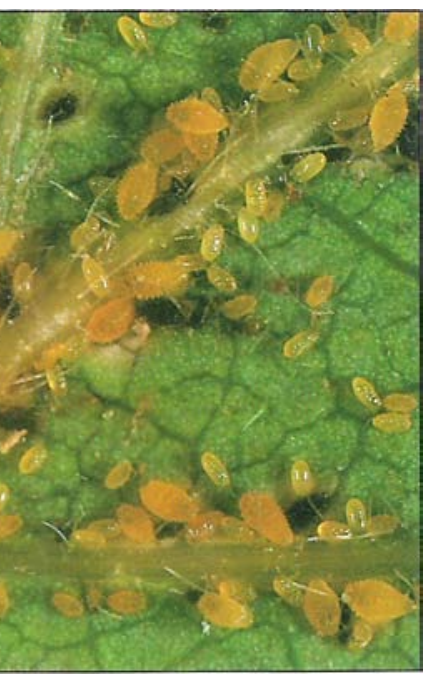

there was no difference in branch number between tall and short plants, and this practice of clipping terminals apparently reduced marketability, probably due to pruning too late.

\section{Industry opportunity, need}

Friends of the Davis Arboretum plant sale customers are mostly homeowners ( $72 \%)$, well educated $(77 \%$ had at least a Bachelor's degree) and average $\$ 45,000$ in annual household income. This is a desirable clientele for commercial nurseries. Most people $(71 \%)$ attend the Friends sale because they desire unique

Oak leaf phylloxera, damaged versus undamaged leaf. Photo by Jack Kelly Clark

less than about one insect of each pest or potential pest species per leaf.

\section{Only certain types of damage seen}

Valley oaks with leaves heavily spotted from oak leaf phylloxera feeding took four times as long to sell (an average of 2 hours) compared with lightly spotted oaks (table 2). Ceanothus 'Concha' with one to three stem galls infested by the Ceanothus stem gall moth took twice as long to sell as undamaged Ceanothus. However, all of the intensely blue-flowering Ceanothus, including galled specimens, were selected by customers before most undamaged Ceanothus of other species or cultivars were sold.

Certain types of damage had little or no effect on customer preference. Customers did not discriminate between undamaged toyon and plants with several partially necrotic leaves of unknown cause. Katydid chewing, or chewing and necrosis, on redbud leaves and agromyzid mining in Verbena hybrida foliage also did not significantly reduce plant marketability.

Baccharis, with leaves heavily stippled by lace bug feeding, sold significantly faster than less damaged Baccharis. Customers may have preferred the more silvery appearance of stippled foliage or preferred the significantly smaller leaves (averaging 7 versus $11 \mathrm{~mm}$ long) on the more damaged Baccharis. It was not possible to separate the effect on customer preference caused by lace bug damage versus leaf size.

Customers did prefer taller oak, Ceanothus, redbud and toyon, which also had more leaves. For example, toyon averaging $1 \frac{1}{2}$ feet tall sold twice as fast as 1foot-tall plants ( $1 \frac{1 / 2}{2}$ versus 3 hours). Toyon terminals were clipped in the nursery to promote the lateral growth characteristic of this multibranched shrub. However, plants not readily available from commercial nurseries. However, our aesthetic injury study focused on relatively common species, because these are commercially available.

The relationship among pest density, plant injury and customer tolerance of damage is undocumented for virtually all ornamental nursery plants. Better information on California natives and ornamental plants from other areas with a similar climate might encourage the nursery industry to provide more of these species, which are generally well adapted to California soils and rainfall. Customer disdain of certain types of plant injury demonstrates that pests causing this damage must be controlled or sales will suffer. Some damage, however, is not discerned by customers. Complete control of certain pests is not required to sell some plants and some nursery pest control practices may be unnecessary. Even in the absence of quantitative thresholds, regular monitoring and decision-making by a person trained in pest management can significantly reduce pesticide use in the nursery without reducing plant marketability.

M. L. Flint is Director, IPM Education and Publications, and Extension Entomologist, Department of Entomology; S. H. Dreistadt is Senior Writer, IPM Education and Publications; E. M. Zagory is Nursery Manager, University Arboretum; R. Rosetta was, IPM intern and graduate student, all at UC Davis.

Warren Roberts, Pam Rener, Jim Salyards and Parker Sanderson provided assistance. Timothy D. Paine, Margaret Algazi and Richard Cowles provided helpful critiques of our manuscript. Friends of the Davis Arboretum, Institute of Museum Services, U.S. Department of Agriculture Smith Lever Project and the University of California Statewide IPM Project provided financial support. Systematists with the Analysis and Identification Unit, California Department of Food and Agriculture, provided pest identifications. 